\title{
Анализ распространения полиморфного варианта rs5219 гена KCNJ11 в популяции ингушей
}

\author{
() М.А. Джаубермезов ${ }^{1,2 *}$, Э.Т. Мингажева ${ }^{1,2}$, А.Б. Якупова ${ }^{1}$, Н.В. Екомасова ${ }^{1,2}$, \\ Э.К. Хуснутдинова ${ }^{1,2}$ \\ ${ }^{1}$ Башкирский государственный университет \\ Россия, Республика Башкортостан, 450076 г. Уфра, улица Заки Валиди, 32. \\ ${ }^{2}$ Институт биохимии и генетики - обособленное структурное подразделение \\ ФГБНУ Уфимского федерального исследовательского центра РАН \\ Россия, 450054, Республика Башкортостан, Уфра, проспект Октября, 71. \\ *e-mail: murat-kbr@mail.ru
}

Сахарный диабет 2 типа является многофакторным заболеванием. Развитие данного заболевания связано со сложным взаимодействием различных генов и фракторов окружающей среды. Полиморфизм rs5219 гена KCNJ11 является фрактором риска развития сахарного диабета 2 типа. Ген KCNJ11 кодирует белок Kir6.2, который формирует внутреннюю часть калиевых каналов в бета-клетках поджелудочной железы. Данное исследование направлено на изучение полиморфизма rs5219 гена KCNJ11 в популяции ингушей, чей язык относится к вайнахской группе северокавказской языковой семьяи. Генотипирование проводили с помощью ПЦР в режиме реального времени с использованием конкурирующих TaqMan-зондов. Частота варианта 23Lys в выборке ингушей составила $37,79 \%$ (95\% Cl: 30,5-45,5).

Ключевые слова: ингуши, KCNJ11, калиевый канал, генотипирование

В последние годы частота диагностирования сахарного диабета в мире неуклонно растёт, этому способствует рост урбанизации, ведение малоподвижного образа жизни и пр. [1,2]. По оценочным данным количество людей, страдающих данным заболеванием во всем мире к 2040 году может составить более 640 млн. [3,4]. Ген KCNJ11 (11p15.1) содержит один экзон и кодирует белок Kir6.2, который образует внутреннюю часть аденозинтрифосфат-чувствительного ионного калиевого канала в бета-клетках поджелудочной железы и играет решающую роль в секреции инсулина [5]. Полиморфизм rs5219 гена KCNJ11 характеризуется заменой гуанина $(G)$ на аденин (A) в кодоне 23, что приводит к замене глутаминовой (Gln) кислоты на лизин (Lys), что приводит к увеличению секреции инсулина [6-8].

Ранее уже было описано распределение частот аллелей и генотипов полиморфного варианта rs5219 в различных популяциях мира. Так, максимальные значения рискового аллеля были выявлены в популяциях Южной Азии (40\%), а также в популяциях Европы (35\%) [9]. Популяции Африки характеризуются минимальными значениями (2\%) [9].

Актуальность данного исследования высока в связи с отсутствием данных о распределении частот аллелей rs5219 в популяциях Северного Кавказа и, в частности, ингушей.

Целью настоящей работы является изучение частот аллелей rs5219 гена KCNJ11 в популяции ингушей. 
Нами была проанализирована ДНК, выделенная из лейкоцитов периферической венозной крови в общей сложности 86 неродственных ингушей с территории Республики Ингушетия (Российская Федерация). В результате анкетирования была установлена этническая принадлежность исследуемых индивидов с указанием предков до третьего поколения. От всех участников было получено информированное согласие на участие в исследовании.

Выделение ДНК из периферической крови осуществляли стандартным методом фенол-хлорофрормной экстракции [10]. Забор крови осуществлялся в фрирменные пробирки Vacutainer®, с использованием 0,5 М раствора ЭДТА в качестве консерванта, после чего пробирки встряхивали и хранили при температуре $4^{\circ} \mathrm{C}$.

Генотипирование полиморфного локуса rs5219 гена KCNJ11 осуществляли методом ПЦР в режиме реального времени по технологии TaqMan. Популяционные частоты аллельных вариантов вычисляли на основе наблюдаемых частот генотипов. Оценку соответствия частот генотипов равновесию Харди-Вайнберга проводили с использованием критерия $X 2$ Пирсона (при р> 0,05). Достоверность различий в частотах аллелей между исследованными выборками вычисляли по критерию X2 с применением поправки Йейтса на непрерывность.

Нами было изучено распределение частот аллелей и генотипов полиморфного локуса rs5219 гена KCNJ11 в популяции Восточного Кавказа. В исследованной выборке ингушей распределение частот генотипов соответствует равновесию Харди-Вайнберга (табл. 1). В популяции ингушей частота минорного аллеля составила $37,79 \%(30,5-$ 45,5) что соответствует диапазону частот, встречающихся в европейских и азиатских популяциях.

Таблица 1. Распределение генотипов rs5219 гена KCNJ11 в популяции ингушей

\begin{tabular}{|l|c|c|c|c|c|c|}
\hline Популяция & $\mathrm{N}$ & \multicolumn{3}{|c|}{ Генотипы } & $\begin{array}{c}\text { Частота минорного ал- } \\
\text { леля (95\% ДИ) }\end{array}$ & $\mathrm{x} 2$ \\
\cline { 3 - 5 } & & $G G$ & $G A$ & $A A$ & & \\
\hline Ингуши & 86 & $\begin{array}{c}33 \\
(38,37 \%)\end{array}$ & $\begin{array}{c}41 \\
(47,67 \%)\end{array}$ & $\begin{array}{c}12 \\
(13,95 \%)\end{array}$ & $37,79 \%(30,5-45,5)$ & 0,8970 \\
\hline
\end{tabular}

Частоты аллелей в изученной популяции ингушей, а также достоверность различий приведена в сравнении с популяциями, данные по которым получены из литературных источников (табл. 2). В связи с тем, что частота минорного аллеля в популяции ингушей сопоставима с таковыми в европейских и азиатских популяциях и существенно отличается от африканских, для сравнения были использованы данные по распределению частот в популяциях европейского и азиатского континентов, а также коренного населения Америки. Статистические различия обнаружены между популяцией ингушей и популяцией англичан, а также коренными народами Америки (табл. 2). 
Таблица 2. Частота минорного аллеля в выборке ингушей и в некоторых мировых популяциях, а также сравнение популяций (p-value)

\begin{tabular}{|c|c|c|c|}
\hline Популяция & $\mathrm{N}$ & Частота минорного аллеля & Ингуши \\
\hline Ингуши* & 86 & $37,79 \%$ & \\
\hline Финляндия [9] & 99 & $44 \%$ & 0,233 \\
\hline Англия и Шотландия [9] & 91 & $26 \%$ & $\underline{\mathbf{0 , 0 2 8}}$ \\
\hline Испания [9] & 107 & $38 \%$ & 0,999 \\
\hline Тоскана, Италия [9] & 107 & $29 \%$ & 0,068 \\
\hline Европа в общем [9] & 503 & $35 \%$ & 0,584 \\
\hline Бангладеш [9] & 86 & $41 \%$ & 0,581 \\
\hline Пакистан [9] & 96 & $44 \%$ & 0,251 \\
\hline Коренное население Америки [9] & 347 & $40 \%$ & $\underline{\mathbf{0 , 0 3 7}}$ \\
\hline
\end{tabular}

Таким образом, в данном исследовании впервые изучен полиморфизм rs5219 гена KCNJ11 в популяции ингушей, населяющих горные и предгорные области восточной части Северного Кавказа. В изученной популяции вариант 23Lys встречается с частотой, характерной для европейских и азиатских популяций. Эти особенности следует учитывать при ассоциативных и фрармакогенетических исследованиях.

Работа поддержана программой поддержки биоресурсных коллекций (Коллекция биологических материалов человека ИБГ Уфимский федеральный исследовательский центр РАН).

Исследование выполнено в рамках государственного задания Министерства науки и высшего образования РФ (FZWU-2020-0027).

\section{Литература}

1. Gupta, M. K., \& Vadde, R. In silico identification of natural product inhibitors for Ysecretase activating protein, a therapeutic target for Alzheimer's disease // Journal of Cellular Biochemistry. 2018. V. 120(6). P. 10323-10336.

2. Huang, Z., Liao, Y., Huang, R., Chen, J., \& Sun, H. Possible role of TCF7L2 in the pathogenesis of type 2 diabetes mellitus // Biotechnology \& Biotechnological Equipment 2018. V. 32(4). P. 830-834.

3. Ogurtsova, K., da Rocha Fernandes, J. D., Huang, Y., Linnenkamp, U., Guariguata, L., Cho, N. H., Makaroff, L. E. IDF Diabetes Atlas: Global estimates for the prevalence of diabetes for 2015 and 2040 // Diabetes Research and Clinical Practice. 2017. V. 128, 40-50. 
4. Sun, P., Liu, L., Chen, J., Chen, Y., Shi, L., Imam, M. U., Fu, X. The polymorphism of rs266729 in adiponectin gene and type 2 diabetes mellitus: A meta-analysis // Medicine. 2017. V. 96(47), e8745.

5. Osama Makhzoom, Younes Kabalan, Faizeh AL-Quobaili Association of KCNJ11 rs5219 gene polymorphism with type 2 diabetes mellitus in a population of Syria: a casecontrol study // BMC Med Genet. 2019. V. 20: 107.

6. Haghvirdizadeh P, Mohamed Z, Abdullah NA, Haghvirdizadeh P, Haerian MS, Haerian BS. KCNJ11: genetic polymorphisms and risk of diabetes mellitus // J Diabetes Res. 2015. P. 908152.

7. Wang DD, Chen X, Yang Y, Liu CX. Association of Kir6.2 gene rs5219 variation with type 2 diabetes: a meta-analysis of 21,464 individuals // Prim Care Diabetes. 2018. V. 12(4) P. 345-353.

8. Schwanstecher C, Meyer U, Schwanstecher M. KIR6.2 polymorphism predisposes to type 2 diabetes by inducing over-activity of pancreatic b-cell ATP-sensitive $\mathrm{K}$ channels // Diabetes. 2002. V. 51. P. 875-879.

9. The 1000 Genomes Project Consortium.

10. Mathew, C. G. The isolation of high molecular weight eukaryotic DNA // Methods Mol. Biol. 1984. V. 2. P. 31-34.

\section{Analysis of the distribution of the rs5219 polymorphic variant of the KCNJ11 gene in the Ingush population}

M.A. Dzhaubermezov ${ }^{1,2}$ * , E.T. Mingazheva ${ }^{1,2}$, A.B. Yakupova ${ }^{1}$, N.V. Ekomasova ${ }^{1,2}$, E.K. Khusnutdinova ${ }^{1,2}$

${ }^{1}$ Bashkir State University

Russia, Republic of Bashkortostan, 450076 Ufa, street Zaki Validi, 32.

${ }^{2}$ Institute of Biochemistry and Genetics is a separate structural unit of the Ufa Federal Research Center of the Russian Academy of Sciences

Russia, 450054, Republic of Bashkortostan, Ufa, Prospekt Oktyabrya, 71.

*e-mail: murat-kbr@mail.ru

Type 2 diabetes mellitus is a multifactorial disease. The development of this disease is associated with a complex interaction of various genes and environmental factors. The rs 5219 polymorphism of the KCNJ11 gene is a risk factor for the development of type 2 diabetes. The KCNJ11 gene encodes the Kir6.2 protein, which forms the interior of the potassium channels in the beta cells of the pancreas. This study is aimed at studying the rs5219 polymorphism of the KCNJ11 gene in the Ingush population, whose language belongs to the Vainakh group of the North Caucasian language family. Genotyping was performed by realtime PCR using competing TaqMan probes. The frequency of the 23Lys variant in the sample of Ingush was 37,79\% (95\% Cl: 30,5-45,5).

Key words: Ingush, KCNJ11, potassium channel, genotyping 